Sari Pediatri, Vol. 6, No. 1, Juni 2004: 52-56

\title{
Keputusan Klinik Dalam Penggunaan Antibiotik
}

\author{
Taralan Tambunan
}

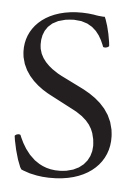
ejak era antibiotik modern dimulai tahun $1936^{1}$ telah banyak penyakit infeksi yang dapat diatasi, sehingga mortalitas menurun tajam. Berbagai penemuan antibiotik golongan terbaru bermunculan sejalan dengan perkembangan ilmu kedokteran. Saat ini lebih dari $30 \%$ pasien yang dirawat di rumah sakit mendapat satu atau lebih antibiotik selama perawatan. Data yang diperoleh satu dekade yang lalu menyebutkan bahwa antibiotik adalah golongan obat yang dikonsumsi terbanyak di Indonesia yaitu sekitar 27\% dari semua biaya obat yang digunakan ${ }^{2}$. Survei sederhana yang dilakukan di Bagian Ilmu Kesehatan Anak-RSCM Jakarta tahun 2001 menunjukkan bahwa 56\% resep yang ditulis di poliklinik berisi satu atau lebih antibiotik. Angka tersebut menurun 1 tahun kemudian menjadi 42\% setelah dilakukan beberapa kali penyuluhan dan seminar penggunaan antibiotik yang rasional ${ }^{3}$. Di samping manfaat yang diperoleh, pemakaian antibiotik yang tidak terkendali dapat membawa dampak yang merugikan.

Berbagai data penelitian menyebutkan bahwa antibiotik adalah obat yang paling sering digunasalahkan (misused) oleh para dokter ${ }^{1}$, antara lain pemakaian antibiotik pada infeksi saluran nafas akut yang sebenarnya lebih dari 50\% adalah infeksi virus yang tidak perlu pemberian antibiotik. ${ }^{4} \mathrm{Hal}$ yang paling mengkhawatirkan akhir-akhir ini adalah isu global munculnya kuman patogen yang resisten ${ }^{4}$, oleh sebab itu para dokter terutama para klinikus diharapkan bersikap bijaksana dan selektif dalam penggunaan obat, khususnya antibiotik.

Alamat Korespondensi:

Prof. Dr. Taralan Tambunan, Sp.A(K).

Subbagian Nefrologi. Bagian Ilmu Kesehatan Anak FKUI-RSCM, Jl. Salemba 6, Jakarta 10430.

Tel. 021- 391 5179. Fax. 3913982.

\section{Penggunaan antibiotik rasional}

Seorang klinikus yang profesional harus mampu menegakkan diagnosis yang akurat, menguasai patogenesis dan patofisiologi penyakit, memiliki pengetahuan farmakologi dasar, farmakokinetik dan farmakodinamik obat yang dipergunakan untuk diterapkan di klinik. Obat hanya boleh diresepkan apabila memang diperlukan, setelah menimbang manfaat dan risikonya. Faktor-faktor yang harus dipertimbangkan dalam membuat keputusan pengobatan yang rasional tertera pada Gambar 1.5 Penulisan resep obat yang tidak rasional dapat berakibat pengobatan tidak efektif, kurang aman, memperpanjang penderitaan pasien, berbahaya bagi pasien, dan menambah biaya pengobatan ${ }^{6}$. (Gambar 1)

WHO tahun 1994 telah menerbitkan buku panduan The guide to good prescribing khususnya untuk mahasiswa kedokteran, sebagai buku pedoman dalam proses penulisan resep obat yang rasional ${ }^{7}$. Langkahlangkah sistematis penggunaan obat yang disusun oleh WHO tersebut adalah sebagai berikut,

- Mendefinisikan/menentukan diagnosis dan masalah yang dihadapi

- Menentukan tujuan pengobatan secara spesifik

- Seleksi obat untuk pasien secara pribadi (personal drugs)

- Penulisan resep

- Pemberian informasi yang adekuat

- Pemantauan dan bila perlu penghentian obat

Langkah-langkah tersebut di atas dapat dipakai sebagai pedoman pemakaian antibiotik

\section{Pemilihan Antibiotik}

Pemilihan antibiotik yang tepat harus diawali dengan upaya diagnostik yang akurat serta tujuan pengobatan yang lebih spesifik sesuai dengan langkah 1 dan 2 
pedoman WHO tersebut. Dalam penanganan penyakit infeksi, faktor mikrobiologi serta aspek farmakologik obat sangat penting. Sayangnya keputusan untuk memakai antibiotik sering tidak didasari data klinik dan laboratorik yang memadai dan sering kurang memperhatikan aspek farmakologik obat yang dipilih. Pemakaian antibiotik yang hanya didasarkan adanya demam sebagai tanda infeksi sangat tidak rasional dan potensial dapat membahayakan pasien.

Pemilihan antibiotik harus didasarkan atas spektrum antibiotik, efektivitas klinik, keamanan, kenyamanan dan cocok tidaknya obat yang dipilih untuk pasien bersangkutan, biaya atau harga obat, serta potensi untuk timbulnya resistensi dan risiko superinfeksi ${ }^{2}$. Di atas segalanya pemilihan perlu didasarkan atas bukti klinis hasil-hasil penelitian (evidence base), karena hasil uji kepekaan invitro saja tidak cukup untuk menjamin keberhasilan klinis. Secara umum, antibiotik digunakan dalam tiga cara yaitu sebagai terapi empiris, terapi definitif dan sebagai profilaksis atau pengobatan preventif.

\section{Terapi Empiris}

Bila dipakai sebagai terapi empiris atau terapi awal, spektrum antibiotik pilihan sedapat mungkin mencakup semua kuman patogen yang dicurigai karena kuman penyebab secara pasti belum diketahui. Setelah kuman penyebab dapat diidentifikasi dan uji kepekaan telah diperoleh, harus segera dilanjutkan dengan terapi definitif dengan memilih antibiotik berspektrum sempit, toksisitas rendah serta cocok untuk pasien dengan mempertimbangkan faktor individual pasien misalnya ada tidaknya faktor alergi.

\section{Penyakit akut}

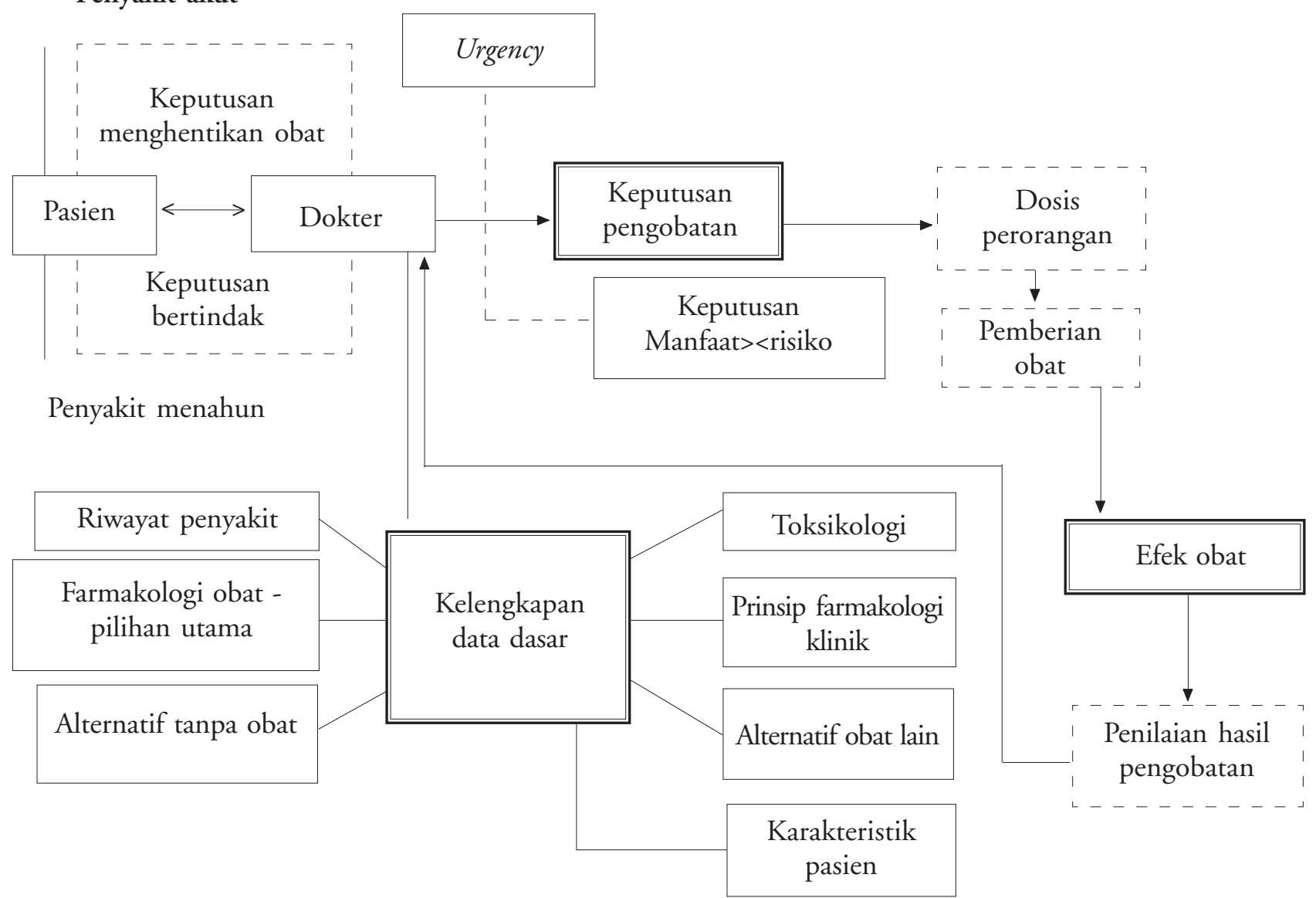

Gambar 1. Pengambilan keputusan pengobatan berdasarkan pertimbangan farmakologi klinis. Dimodifikasi dari Mc Leod ${ }^{5}$ 
Pemilihan antibiotik berspektrum sempit bertujuan untuk mengurangi kemungkinan terjadinya resistensi dan superinfeksi ${ }^{2}$.

Pemilihan antibiotik sebagai terapi empiris memerlukan pengetahuan tentang kemungkinan kuman penyebab dan kerentanannya terhadap antibiotik. Gambaran klinik tertentu mungkin dapat mengarah pada kuman tertentu. Pemeriksaan laboratorium sederhana dan cepat seperti pulasan Gram sangat membantu mengindentifikasi kuman termasuk Gram negatif atau Gram positf; dengan demikian pemilihan antibiotik sudah lebih terarah dan lebih rasional. Namun ada kalanya gejala klinik spesifik tidak ditemukan serta upaya identifikasi kuman tidak sampai pada diagnosis bakteriologis yang spesifik, sehingga pemilihan antibiotik berspektrum sempit menjadi kurang tepat, terutama bila penyakit infeksi yang dihadapi cukup serius dan mengancam nyawa pasien. Dalam hal ini pemilihan antibiotik berspektrum luas menjadi relevan, namun pemilihan antibiotik harus dilakukan atas dasar kuman penyebab tersering yang ditemukan melalui data epidemologis. Meskipun demikian biakan kuman dari tempat infeksi maupun biakan darah harus dilakukan sebelum pemberian antibiotik, dengan maksud untuk mengetahui jenis kumannya bila pengobatan empiris pertama mengalami kegagalan, misalnya pada infeksi saluran kemih, dengan demam tifoid, atau sepsis ${ }^{2}$.

Bila data pendukung untuk terapi empiris maupun data epidemologis tidak tersedia maka upaya pemilihan obat dapat dilakukan dengan pendekatan stepped care atau lebih dikenal dengan educated guess. Pemilihan obat didasarkan atas perkiraan jenis kuman yang paling mungkin, pola resistensi, dan organ yang terkena. Jenis kuman yang menyerang organ tertentu dapat diduga dengan cukup akurat. Infeksi di kulit misalnya sering disebabkan oleh kuman streptokok atau stafilokok. Infeksi saluran kemih umumnya disebabkan oleh kuman gram negatif. Pola resistensi kuman umumnya sudah diketahui dan lebih baik lagi bila pusat-pusat laboratorium mikrobiologi setempat dapat memberikan informasi tentang pola kuman secara berkala. Dengan pengetahuan pola kuman dan resistensinya seorang klinikus dapat menentukan pilihan antibiotik yang cukup akurat tanpa melakukan biakan kuman.

Dengan adanya sedemikian banyak jenis antibiotik dalam satu kelas terapi maka pendekatan educated guess adalah logis dan rasional. Tabel obat pilihan pertama dan kedua yang disusun berdasarkan organ yang terkena dan kemungkinan kuman penyebab sangat membantu para klinikus dalam menentukan pilihan antibiotik terhadap pasiennya. Namun disadari bahwa upaya menyusun tabel obat seperti ini tidak mudah dan dapat menjadi perdebatan yang berkepanjangan akibat perbedaan pandangan maupun pengalaman klinik seorang dokter dengan dokter lainnya. Di samping itu banyak obat, baik dalam satu golongan maupun tidak, memiliki efektivitas yang setara dan disadari sulit membuat ranking efektivitas obat baik melalui uji kepekaan maupun berdasarkan hasil berbagai uji klinik.

Pendekatan stepped care ataupun educated guess ini tentu tidak dapat menggantikan cara pemilihan antibiotik berdasarkan hasil biakan kuman dan uji kepekaan. Meskipun demikian daftar obat yang disusun dalam berbagai tabel educated guess setidaktidaknya telah melalui proses yang cukup cermat dengan mempertimbangkan faktor pengalaman beberapa pakar serta hasil uji klinik berbagai institusi yang terkemuka untuk digunakan sebagai dasar terapi atau terapi empiris. Di antara tabel educated guess yang cukup informatif dan sistematis misalnya tabel yang tertera dalam buku teks Goodman \& Gilmans The pharmacological basis of therapeutics edisi ke 10 tahun $2001^{1}$ yang disusun berdasarkan jenis kuman, penyakit atau organ yang terkena infeksi serta prioritas pilihan antibiotik. Tabel tersebut juga dilengkapi berbagai keterangan misalnya alasan pemilihan antibiotik tertentu (Tabel 1).

Buku pedoman penggunaan antibiotik yang dikeluarkan oleh Komite Farmasi-Terapi Universitas Wisconsin di Amerika Serikat juga sangat baik sebagai buku acuan karena buku tersebut memuat tabel daftar obat yang disusun secara alfabet, berdasarkan jenis kuman, pemilihan secara empiris, profilaksis maupun pilihan obat berdasarkan organ yang terkena infeksi ${ }^{8}$. Dengan kata lain, informasi tentang pemilihan obat, khususnya antibiotik tersedia cukup banyak dan dapat diakses melalui perpustakaan kedokteran maupun media internet, asalkan para klinikus mau meluangkan sedikit waktunya untuk mengakses sumber informasi tersebut.

\section{Terapi Definitif}

Untuk pengobatan definitif, biakan kuman dan uji 
kepekaan penting untuk menentukan obat pilihan yang paling tepat. Biakan kuman dan uji kepekaan yang dilakukan dengan baik adalah cara yang paling tepat untuk menentukan pilihan antibiotik. Salah satu kelemahan pemeriksaan biakan kuman yaitu faktor waktu. Biakan kuman membutuhkan waktu 3-7 hari dan ini sangat menyulitkan terutama bila yang dihadapi adalah kasus dengan infeksi berat seperti pielonefritis, sepsis, demam tifoid dan sebagainya. Dalam pemilihan obat, faktor-faktor yang harus diperhitungkan antara lain efektivitas obat, keamanan, kecocokan dengan pasien, harga obat serta ketersediaan obat. Oleh sebab itu pengetahuan tentang aspek farmakokinetik dan farmakodinamik obat perlu dikuasai oleh seorang dokter yang menangani pasien. Informasi tentang efektivitas obat, keamanan, keadaan pasien, keparahan penyakit yang diderita, riwayat pemakaian obat yang pernah diperoleh, faal hati, fungsi ginjal serta faktor lainnya yang ada kaitannya dengan obat yang akan dipilih seperti usia, riwayat alergi, faktor genetik, keadaan hamil dan sebagainya ${ }^{1}$.

\section{Terapi Kombinasi Antibiotik}

Penggunaan dua jenis antibiotik dapat dibenarkan pada keadaan tertentu. Tetapi pemilihan terapi kombinasi perlu hati-hati kemungkinan terjadinya interaksi obat dan peningkatan toksisitas obat $^{1}$. Tujuan terapi kombinasi antibiotik antara lain, ${ }^{1}$

- Sebagai terapi empiris terhadap infeksi yang belum

Tabel 1. Pemilihan antibiotik dalam terapi infeksi menurut pendekatan educated guess

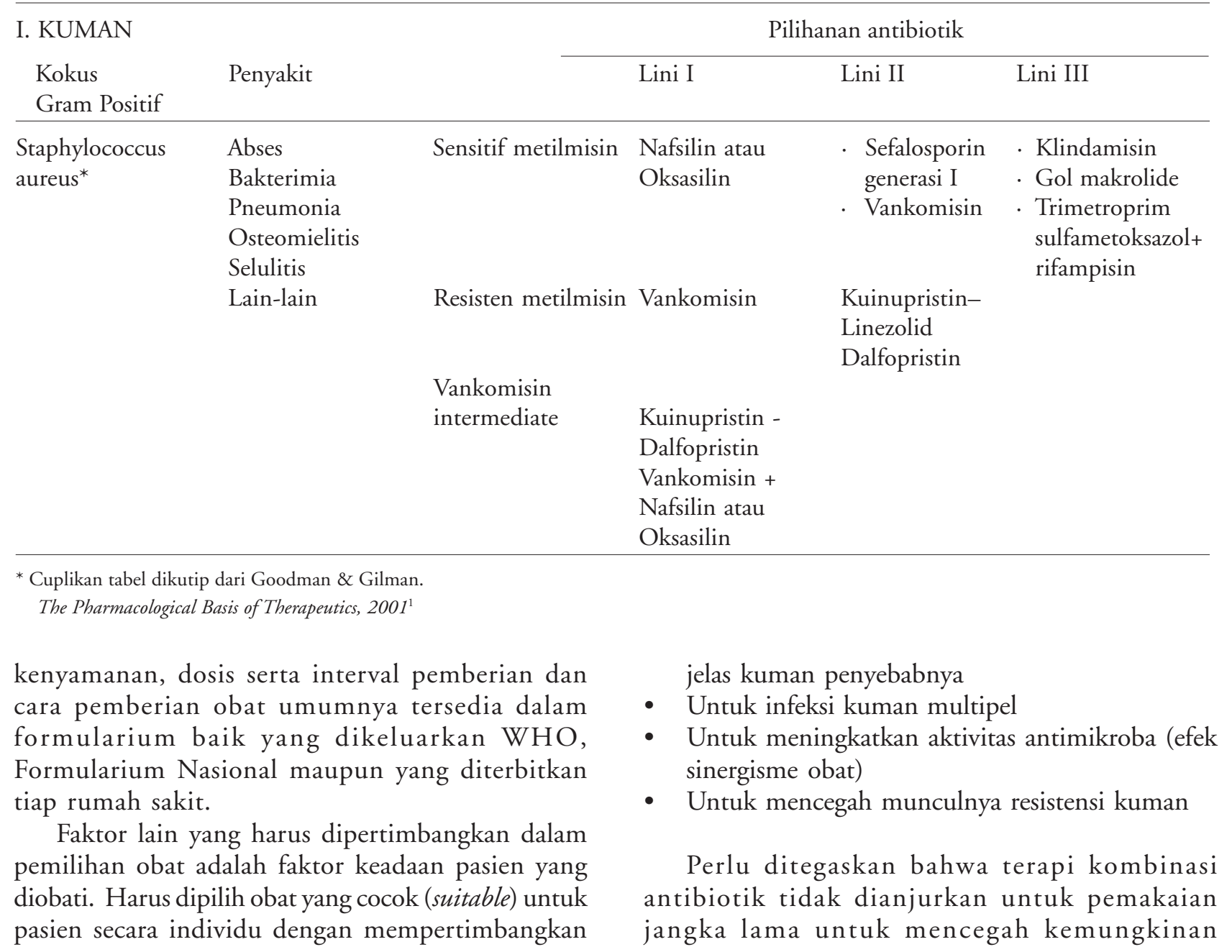


timbulnya toksisitas obat, superinfeksi maupun resistensi obat.

\section{Terapi Profilaksis}

Terapi profilaksis dapat berguna pada keadaan tertentu sedangkan pada keadaan lain mungkin tidak berguna. Pemakaian antibiotik profilaksis sering mengundang kontroversi. Secara umum, bila dipilih obat tunggal yang efektif secara spesifik terhadap kuman tertentu dengan toksisitas yang rendah atau untuk eradikasi infeksi secara dini maka pengobatan tersebut seringkali bermanfaat. Sebaliknya bila profilaksis dimaksudkan untuk menghambat pertumbuhan koloni sejumlah kuman yang mungkin menyerang maka pencegahan seperti ini sering gagal ${ }^{1}$.

Berbagai indikasi profilaksis antibiotik antara lain pencegahan penyakit sifilis atau gonorea bagi pasien yang kontak dengan sumber infeksi, pemakaian kotrimoksazol untuk infeksi saluran kemih, pasien yang menerima transplantasi organ tubuh atau pasien yang mendapatkan obat-obat kemoterapi terhadap keganasan, maupun pada berbagai prosedur tindakan bedah.

\section{Penulisan Resep, Pemberian Informasi serta Pemantauan Pasien}

Langkah pemilihan obat untuk pasien secara individual (personal drugs) harus dilanjutkan dengan langkah selanjutnya yaitu penulisan resep. Penulisan resep yang baik harus memenuhi kaidah-kaidah farmasi yang baku antara lain mengenai dosis obat, jumlah obat yang diresepkan, cara pemberian, interval pemberian dan sebagainya.

Informasi yang adekuat wajib disampaikan kepada pasien dan dibutuhkan kesabaran dan kemampuan komunikasi yang baik agar tujuan pengobatan tercapai. Demikian juga halnya dengan pemantauan (follow up) baik terhdap keberhasilan pengobatan maupun terhadap efek samping yang mungkin timbul. Ringkasnya langkah-langkah sistematis penggunaan obat harus diikuti dan merupakan satu paket yang utuh agar tujuan pengobatan rasional dapat tercapai.

\section{Kesimpulan}

Seorang klinikus yang profesional harus kompeten dalam penanganan pasien secara rasional, termasuk pemberian antibiotik. Langkah-langkah sistematis yang disusun oleh WHO tahun 1994 amat bermanfaat sebagai panduan dan merupakan satu paket yang utuh agar tujuan pengobatan rasional dapat tercapai. Dibutuhkan kerja sama yang erat antara klinikus dengan berbagai disiplin lainnya seperti mikrobiologi klinik, farmakologi klinik, ataupun farmasi klinik dalam suatu wadah Komite Farmasi Terapi baik di tingkat instalasi, rumah sakit maupun di tingkat nasional. Dengan kemauan yang kuat dan konsisten seorang klinikus akan berhasil melaksanakan tugasnya sebagai pengambil keputusan klinis pemakaian antibiotik.

\section{Daftar Pustaka}

1. Chambers HF. Antimicrobial agents. General consideration. Dalam: Hardman JG, Limbird LE, Gilman AG, penyunting. Goodman and Gilmans The pharmacological basis of therapeutics. Edisi ke-10, New York: Mc Graw Hill;2001. h. 1143-69

2. Darmansyah I. Prinsip umum pemberian antibiotik. Dexa Media 1991;4:3-5.

3. Survai peresepan obat di poliklinik IKA RSCM Jakarta: I. Maret 2001; II Agustus 2001, III Maret 2002. Tidak dipublikasi.

4. Centers for diseasee control prevention (CDC) Media relation. Global resistance to antibiotics. From the NIH, September 17, 2003. Dikutip dari http://www.edc.gov/ drugresistancelcommunity/.

5. Mc Leod SM. Clinical pharmacokinetics; a pediatric overview. Dalam: Radde IC, Mc Leod SM, penyunting. Pediatric pharmacology and therapeutics. Edisi ke-2. Louis: Mosby Yearbook Inc, 1993. h. 157-68.

6. WHO model formulary 2002. Rational approach to therapeutics. h. 2-6.

7. The guide to good prescribing. Geneva: WHO;1994, reprinted 2000.

8. Vermeulen, De Muri G, Maki D, Mejikano G, Smith E, Spiegel C, Rough T. Antimicrobial use guidelines. Edisi ke-12. University of Wisconsin Hospital: Farmedia; 2000-2001. h. 67-93. 